\title{
CORRESPONDENCE
}

\section{Bias in the application of the external detector technique}

SIR - In his reply 'In defence of the external detector method in fission track dating' to Gale \& Beckinsale's (1983) comments on a paper by Ross et al. (1982), Green refers repeatedly in a disqualifying manner to our contribution (Storzer \& Wagner, 1982) entitled 'The application of fission track dating in stratigraphy: a critical review'. Rather than entering fruitless discussions on experience and maturity in fission track dating we feel obliged to comment on the geometry factor used in the external track detector technique (ETD).

(1) We are incorrectly quoted that 'Ross et al. were apparently unaware of the efficiency problems in the external detector technique for zircons'. The paper by Ross et al. (1982) had not yet been published during the preparation of our contribution (Storzer \& Wagner, 1982), which refers to an earlier article by Ross et al. (1978). Our statement that 'these latter authors were apparently unaware of the efficiency problems in the external detector technique, and they did not consider the possibility of fossil track fading in zircon. This impedes the unreserved acceptance of their data for stratigraphy' still holds completely true.

(2) We consider the ETD technique, if properly applied, as useful and justified. There are no contrary statements in our publications as implied by Green. Needless to say that the ETD technique has been commonly used in our laboratories for many years.

(3) The efficiency of revealing and counting tracks depends on various parameters such as type of material, crystallographic orientation, radiation damage, etching, kind of microscopic observation, and personal track identification criteria (Wagner, 1981). Consequently, the geometry factor is subjected to any changes of these conditions.

(4) There is no unique value for the geometry factor. It needs to be calibrated for defined experimental conditions and each individual counting person. This does not preclude that it may assume the ideal value of 2.0 under specific conditions.

(5) For physical reasons alone a unique value for the geometry factor $(4 \pi / 2 \pi)$ is impossible among different mineral-external detector combinations because the total range of fission fragments and, by consequence, also their etchable range are strictly material specific. Both, the mean total and the mean etchable range, vary considerably between different kinds of track detectors. This leads, by necessity, to a specific $4 \pi / 2 \pi$ value for each given track detector couple. As shown in the figure, there exists an intimate linear correlation between geometry factor and range ratio of fission fragments. However, this correlation is only valid provided that the latent tracks are etched and counted in both detectors of the couple rigorously with the same efficiency (same degree of track development, and same magnification-optical condition-track identification criterion). It should be noted that the correlation itself is independent of the mode of fission track observation. The $4 \pi / 2 \pi$ values of the detector pairs 1-3 (Fig. 1) were determined by stereo electron microscopy but those of 4-17 by light microscopy. Deviations from the correlation line occur whenever important differences in the track etching/ bulk etching velocity ratios $\left(v_{\mathrm{t}} / v_{\mathrm{b}}\right)$ of the two materials of the detector couple exist, as in the case of glasses and in the case of minerals susceptible to radiation-induced isotropization like sphene and, above all, zircon. Glasses and metamict zircons have greatly lower $v_{\mathrm{b}} / v_{\mathrm{b}}$ ratios than the commonly used external detectors, with the consequence that the ratio of the etchable ranges of fission fragments in the two kinds of detector materials of the couple will be lower than the ratio of the total ranges of the fragments. At the same time, also the $4 \pi / 2 \pi$ value decreases. In other words, a given detector couple will move down the correlation line in function of the difference between the total range ratio and the etchable range ratio. This is shown in Figure 1 for the glass/external detector pairs $9-12$, where only the etchable range ratios fit the correlation line. As to sphenes and zircons coupled with muscovite, the theoretical $4 \pi / 2 \pi$ values predicted from the correlation would be respecitvely 1.66 and 1.46 . However, as the scatter of pairs $13-17$ shows, the actual $4 \pi / 2 \pi$ values

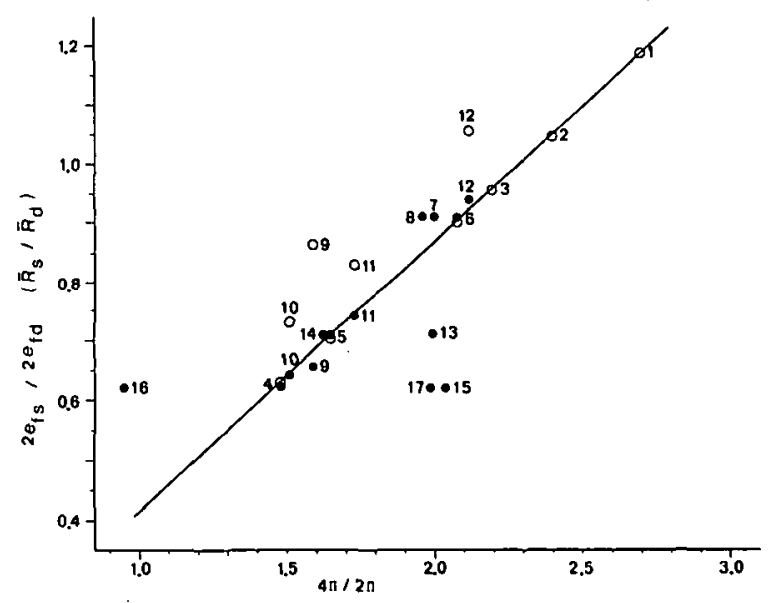

Figure 1. Correlation between the virtual value of the geometry factor $4 \pi / 2 \pi$ and the ratio (internal/external) of fission fragment ranges in various track detector couples (from Sélo, unpublished thèse d'Etat, Paris VI, 1983). $2 e_{\mathrm{fs}} / 2 e_{\mathrm{fd}}$ (closed symbols) and $\bar{R}_{\mathrm{s}} / \bar{R}_{\mathrm{d}}$ (open symbols) are respectively the ratios of the mean etchable and the mean total fission fragment ranges in the two kinds of material of the given detector couple. The fission fragment ranges $e_{\mathrm{r}}$ and $\bar{R}$ in the different track detector materials were determined by Storzer \& Sélo as, unless cited, the corresponding $4 \pi / 2 \pi$ values. All the data are complied in Sélo (unpublished thèse d'Etat, Paris VI, 1983), where the procedure for the calculation of $\bar{R}$ and the different techniques for measuring $e_{\mathrm{f}}$ are also described. The numbers stand for the following track detector couples: 1-3, whitlockite/feldspar-fassaiteolivine (Storzer \& Pellas, 1977); 4-6, apatite/Lexan-Kaptonmuscovite (no. 5: Storzer \& Sélo, 1981); 7-8, apatite/ muscovite (Gleadow \& Lovering, 1977); 9 moldavite glass/Kapton; 10-12, reference glass SRM 615/LexanKapton-muscovite; 13-14, sphene/muscovite (Gleadow \& Lovering, 1977); 15-16, zircon/muscovite (Gleadow \& Lovering, 1977); 17, zircon/muscovite (Naeser, personal communication). 
can be anywhere, depending mainly on the state of metamictization of the mineral to be dated.

In conclusion, there are efficiency problems when applying the EDT technique and we believe that in order to achieve accurate fission track ages with this technique it is wiser to encourage individual calibration rather than to propagate any 'right' value for the geometry factor.

\section{References}

Gale, N. H. \& Beckinsale, R. D. 1983. Comments on the paper 'Fission track dating of British Ordovician and Silurian stratotypes' by Ross and others. Geological Magazine 120, 295-302.

Gleadow, A. J. W. \& Lovering, J. F. 1977. Geometry factor for external detectors in fission track dating. Nuclear Track Detection 1, 99-106.

Green, P.F. 1985. In defence of the external detector method of fission track dating. Geological Magazine 122, 73-5.

Ross, R. J., Naeser, C. W., Izett, G. A., Obradovich, J. D., Bassett, M. G., Hughes, C. P., Cocks, L. R. M., Dean, W. T., InghaM, J. K., Jenkins, C. J., RickaRds, R. B., Sheldon, P. R., Toghill, P., Whittington, H. B. \& ZALASIEWICZ, I. 1982. Fission-track dating of British Ordovician and Silurian stratotypes. Geological Magazine 119, 135-53.

Ross, R. J., NaESer, C. W., Izett, G. A., Whittington, H. B., Hughes, C. P., Rickards, R. B., Zalasiewicz, I., Sheldon, P. R., Jenkins, C. J., Cocks, L. R. M., Bassett, M. G., Toghill, P., Dean, W. T. \& Ingham, J. K. 1978. Fission-track dating of Lower Paleozoic volcanic ashes in British stratotypes. In Short Papers of the Fourth International Conference, Geochronology, Cosmochronology, Isotope Geology (ed. R. E. Zartman), pp. 363-5. United States Geological Survey Open-File Report 78-701.

Storzer, D. \& Pellas, P. 1977. Angra Dos Reis: Plutonium distribution and cooling history. Earth and Planetary Science Letters 35, 285-93.

Storzer, D. \& SéLo, M. 1981. Traces de fission dans des apatites détritiques: application à la reconstitution de l'histoire thermique d'un bassin sédimentaire. Compte Rendu de l' Académie des Sciences de Paris 293 (Série II), 979-84.

Storzer, D. \& Wagner, G. A. 1982. The application of fission track dating in stratigraphy: a critical review. In Numerical Dating in Stratigraphy, Part 1 (ed. G. S. Odin), pp. 199-224. Chichester, New York, Brisbane, Toronto, Singapore: John Wiley and Sons.

WAGNER, G. A. 1981. Fission track ages and their geological interpretation. Nuclear Tracks 5, 15-25.

\section{STORZER}

Laboratoire de Minéralogie du

Museum National d'Histoire Naturelle

61 Rue de Buffon

75005 Paris

France

\section{G. A. WAGNER}

Max-Planck Institut für Kernphysik

Heidelberg

Federal Republic of Germany

20 August 1984 